\title{
The Pedagogies of Performative Afterlife
}

\section{Catherine Spencer}

Many theorizations of the performative, from the late 1980s and 1990s through to the present, have connected it with the processes of teaching, learning and pedagogy. These intersections, however, have often remained latent rather than explicit in analyses of the performative in artistic practice, despite close attention to the intersection between contemporary art and pedagogy. ${ }^{1}$ In what follows, I focus specifically on the pedagogic function of the performative in performance art and its histories. This plays a crucial role in artistic and curatorial projects engaging with the afterlives of performance art from the 1960s and 1970s, which have enjoyed exponential growth since the early 2000s. The term 'afterlife' in this context denotes the tangible manifestations of documentation and mediation generated in relation to events and actions, which continue to endure afterwards, such as photographs, films, videos, scores and archival ephemera. It also extends beyond physical traces to encompass the transient speech acts of reportage and discourse, together with embodied, fleeting gestures that can be revivified through repertoires and choreographic notation. ${ }^{2}$ The afterlife of performance is not automatically synonymous with performative afterlife, but the practitioners considered in this article all approach it as able to act performatively in and on the present, by creating pedagogic opportunities for learning and dialogic exchange between subjects. ${ }^{3}$ This capacity of the pedagogic performative entails that it has become especially prominent in works by artists who challenge restrictive understandings of class, gender, sexuality and race, and who draw on feminist, queer and critical race theory to do so.

Artistic initiatives that return to prior performance artworks and, more generally, earlier political moments, have proliferated since the millennium. ${ }^{4}$ Such projects are discussed using the interchangeable but nonetheless distinct terms re-performance, reenactment and reinvention. ${ }^{5}$ For the purposes of this article, the designations 'reenactment' and 'reinvention' are understood to be most relevant to the operation of performative pedagogy, in that they signal an enabling critical distance from the source material cited. ${ }^{6}$ The impulses powering this intense attraction to the 're' factor are multiform, and, as itemised by the curator Andrea Tarsia, include 'a broader reappraisal of conceptual and experimental art from the period [of the 1960s and 1970s]; the re-emergence of its legacies and processes in the work of younger generations of artists; [and] the return of participatory and situational practices that foregrounded events, activities and audience participation. ${ }^{7}$ We can add to this the historiographical institutionalisation of performance art, in conjunction with an increased curatorial enthusiasm for 'experiential' practice within museums. ${ }^{8}$ When considering the demands made by the afterlives of performance, however, there is another important element in play, articulated by Heike Roms as 'an intellectually affective charge, which emanates from the ideas that these documents promise to give access to'. ${ }^{9}$ Many re-enactments and reinventions, whether initiated by artists, curators, or organizations, are predicated on the premise that archival and embodied afterlives are charged with intellectual and pedagogic potential, and that the encounter with them will be an educational one for practitioners, audiences and institutions alike. These educational impulses range from the desire to learn about the past 
through return, attempts to use the past to inform present or future actions, and the compulsion to create anew from existing matter and thereby redress history.

The conviction that teaching is a performative activity underpins many accounts of alternative and anti-hierarchical pedagogies, notably those that aspire to dismantle forms of authority. In Teaching to Transgress: Education as the Practice of Freedom (1994), bell hooks asserts that 'teaching is a performative act' which opens up 'space for change, invention, spontaneous shifts', and can serve 'as a catalyst drawing out the unique elements in each classroom'. ${ }^{10}$ This approach is intimately connected with the production of what José Esteban Muñoz terms 'minoritarian knowledge'; hooks draws directly on her experience as a black woman navigating a racist, patriarchal society in her theorization of learning. ${ }^{11}$ hooks' emphasis on change and becoming echoes the understanding of the performative developed by Judith Butler, building on the philosopher J. L. Austin's theory of performative speech acts. Austin famously defined the performative speech act as occurring in situations whereby 'to utter the sentence (in, of course, the appropriate circumstances) is not to describe my doing of what I should be said in so uttering to be doing or to state that I am doing it: it is to do it. ${ }^{12}$ In deploying the performative to propound the contingency of gender identity, Butler acknowledges the potentially restrictive aspect of such illocutionary acts, noting their predominance in 'legal sentences, baptisms, inaugurations, declarations of ownership,' all of which 'not only perform an action, but confer a binding power on the action performed'. ${ }^{13}$ Yet, Butler insists, 'the effects of performatives, understood as discursive productions, do not conclude at the terminus of a given statement or utterance. [...] The reach of their signifiability cannot be controlled by the one who utters or writes'. ${ }^{14}$ It is precisely this continuously transformative property of the performative that shapes hooks' conception of pedagogy.

In emphasising the catalytic qualities of teaching, hooks makes an important distinction between 'performance' and the 'performative' vis-à-vis education, specifying that 'teachers are not performers in the traditional sense of the word in that our work is not meant to be a spectacle' ${ }^{15}$ Performative teaching rejects the performance of knowledge by an authority figure to a subordinated student audience, and favours the orchestration of situations in which knowledge can be created collaboratively. Comparably, in Touching Feeling: Affect, Pedagogy, Performativity (2003), Eve Kosofsky Sedgwick describes how the disorienting experience of 'abyssal displacement' as a teacher in the pedagogic scenario might 'wrench the boundaries of discourse around in productive if not always obvious ways. ${ }^{16}$ These displacements, infused with affectual charge - 'with joy, with chagrin, with intense discomfort' - are illuminated by the notion of the performative that Sedgewick develops in Touching Feeling. ${ }^{17}$ Sedgwick advocates shifting beyond a focus on epistemology and essentializing truth-claims when analysing the performative, moving instead towards a variegated map of performative speech acts, a process that requires asking 'new questions about phenomenology and affect' ${ }^{18}$ These 'new questions' are proposed with the discursive zone of the classroom in mind, a locus where performative acts can be constituted through speech and the body, and identities (re)formulated via learning.

In unfolding her expanded sense of the performative, Sedgwick acknowledges her debt to the literary scholar Shoshana Felman. Felman excavates the pedagogic passions infusing Austin's project, arguing that the titles of his writings, such as 'how 
to do things with words,' 'a plea for excuses,' and 'three ways of spilling ink,' use humour to suspend their claims to entitlement and didacticism, instead offering 'promises of new subjects, promises of authorial authority, promises of knowing or learning'. ${ }^{19}$ These titles, Felman concludes, 'only do something [...] by suspending their own authority to say something, ${ }^{20}$ At the heart of Austin's concept of the performative speech act, Felman discovers a playful subversion of educational authority, the solicitation of scholarly desire through seduction, and an embrace of possible failure. ${ }^{21}$ Muñoz also draws directly on Felman to celebrate 'a theory of minoritarian pedagogy that owns failure, one that sees the process of teaching as being rife with what Austin calls "misfires.",22 Misfires and failures of transmission are inescapable potential outcomes of the performative, and are paradoxically intrinsic to the conditions of its realization.

Questioning authority and embracing the spectre of failure are key aspects of queer and feminist pedagogies. ${ }^{23}$ In her essay 'Authority and Learning,' the feminist artist, critic and teacher Mira Schor elaborates the political potential of these tenets: "humor and community, and the concerted effort to try, if not to ever fully succeed, to undermine traditional, gendered authority structures and to render teaching transparent, can help create a situation in which what cannot be taught - intelligence, drive, self-criticality - can be learned. ${ }^{24}$ These anti-hierarchical attitudes to teaching, developed with an awareness of the lived subjectivities marginalized by traditional models of learning with regards to gender, sexuality, race and class, are indebted to the alternative education methodologies pioneered during the 1960s and early $1970 \mathrm{~s}$ in conjunction with the Civil Rights movement in the US, and global de-colonizing independence movements. hooks, for example, connects her commitment to educational transgression with her own experiences of US racial segregation, and attests to the impact of the radical pedagogue Paulo Freire on her learning and teaching. ${ }^{25}$ In Pedagogy of the Oppressed (1968, first English translation 1970), based on his work in Brazil and Chile, Freire influentially proposed that in order to free oppressed subjects, liberatory pedagogy could not emulate 'models from among the oppressors', but had of necessity to be dialogic. ${ }^{26}$

The legacy of Freire's ideas, together with those of the American pragmatist philosopher and educationalist John Dewey, can be discerned in the development of social art practices that facilitate participation and collaboration. ${ }^{27}$ The growth of participatory work, in which invocations of pedagogy have proved highly influential, can be linked in turn to the art institutional and curatorial prioritization of educational methodologies during the last two decades. Through this 'educational turn', arts organizations have embraced seminars, symposia, lectures, workshops, and other pedagogic tools in their programming, resulting in what Andrea Phillips characterises as 'the use of pedagogy as a utopian socialised site by organisations and individuals outside orthodox educational structures'. ${ }^{28}$ A full account of pedagogy's role in socially engaged art and contemporary curating lies beyond this article's scope, but both phenomena have shaped the cultural framework in which historic performance art has entered the museum institution through re-enactment and reinvention. ${ }^{29}$

It is vital to remember that education, as Felicity Allen writes, 'has been promoted and is experienced as both emancipatory and regulatory,' while the precepts embraced by art education have been thoroughly implemented in neoliberal knowledge economies. ${ }^{30}$ By no means all instances where performance art intersects with the 
pedagogic are emancipatory. This liberatory capacity, I propose, is specific to performative pedagogy. Irit Rogoff describes how 'performative enablement' might result in a 'loosening of frames' that enables subjects to 'move forward more freely, employ and deploy a range of theoretical, methodological and performative rhetoric and modes of operation'. ${ }^{31}$ Throughout the projects that the second part of this article addresses, perfomative pedagogy holds out the generative experimentalism conjured by Rogoff through its instigation of dialogue, interaction and change. Artists including Carey Young, Kate Davis, Clifford Owens and Patrick Staff employ performative pedagogies to explore historical legacies and sound out alternative models for knowledge exchange, while remaining attuned to the power imbalance of the student-teacher relationship and education's disciplinary function. ${ }^{32}$

Their approach correlates with that of Sharon Hayes, whose practice holds a vital place in studies of return, citation, and reiteration, especially in relation to queer temporalities. ${ }^{33}$ For In the Near Future (2005-2009), Hayes positioned herself in public spaces across New York, London, Vienna, Brussels, Warsaw and Paris, holding placards emblazoned with historical protest slogans. Hayes distinguishes In the Near Future from re-performance, stressing instead her interest in the enunciation of performative speech acts. ${ }^{34}$ The result is 'not didactic, but it is pedagogic'. ${ }^{35}$ This refusal of didacticism, building on the long legacy of alternative education, constitutes a central characteristic of the artistic approaches discussed below, which interact performatively with artistic afterlives to bring about new states of possibility.

\section{Performative Pedagogies in Action}

Hayes' assessment of her work as 'pedagogic' but not 'didactic' exemplifies the ambition that the return to historical material through performance can have an educative impact. As Amelia Jones elucidates in relation to Marina Abramović's Seven Easy Pieces (2005), the process of re-enactment testifies both 'to our desire to know the past in order to secure ourselves in the present and the paradox of that knowledge always taking place through repetition'. ${ }^{36}$ However, Abramović's gesture, for which she re-presented six performances from the 1960s and 1970s by artists including VALIE EXPORT, Gina Pane, and Bruce Nauman over consecutive evenings in the Guggenheim museum's rotunda, culminating in a new performance of her own on the seventh and final night, was more didactic than pedagogic. Each performance became a durational tableau vivant, an instructive 'show and tell' image unambiguously displayed with canon formation in mind. ${ }^{37}$ By contrast, Hayes and others have responded to the notion of afterlife in ways that resonate with the theoretical elaborations of performative pedagogy by hooks, Sedgwick, and Muñoz. Carey Young's Body Techniques (2007) is instructive because it ostensibly deploys a similar structure to Seven Easy Pieces. Young comparably 're-worked' performance and conceptual gestures from the 1960s and 1970s by EXPORT, Kirsten Justesen, Richard Long, Nauman, Dennis Oppenheim, Ulrich Rückreim and Mierle Laderman Ukeles. ${ }^{38}$ The results, however, were very different, in that Young treated each work as a lesson to be adapted and reformulated in distinct conditions.

Across eight photographs, Young transposes the embodied actions initiated by her chosen artists to building sites surrounding Sharjah and Dubai. Throughout, she 
dresses in formal business attire, her red, grey and black tailored trouser suits contrasting sharply with the surrounding sun-bleached landscape. The businessperson is a 'character' that Young frequently adopts, conceived 'as a device to discuss complicity and to question clichéd ideas of artistic withdrawal as a critical strategy'." In Body Techniques (after A Line in Ireland, Richard Long, 1974), Young picks her way along a mound of shale, arms outstretched like a tightrope walker. A spectral city shimmers on the horizon through the dust and haze, its armature of nascent skyscrapers stitched together by busy cranes (Figure 1). Devoid of human presence, these construction areas are uncannily familiar, built using an architectural vernacular replicated across commercial and financial districts worldwide. Young vividly enacts how neoliberal globalisation shapes and disciplines the embodied subject. This is underscored by her titular reference to the anthropologist Marcel Mauss' 1934 lecture 'Techniques of the Body', which posited that bodily actions and gestures are overwhelmingly conditioned by the wider socio-cultural fields in which they are executed. ${ }^{40}$ Equally, by merging artist with businessperson, and staging a reciprocal relationship between this figure and the homogenous landscapes of globalised service industries, Body Techniques acknowledges art's complicity in the very processes that Young critiques, underlining the ease with which art world mechanisms smoothly digest such critique and re-deploy it as cultural capital. ${ }^{41}$

Analysing Young's work, Alex Farquharson notes that 'never before have the lexicons of contemporary art and leading-edge business, with their mutual emphases on discovery, creativity, and innovation, sounded so alike'. ${ }^{42}$ The fusion of subject and habitat in Body Techniques conveys how the innovations of artists during the 1960s and 1970s - their emphasis on the experiential, de-skilling, and information exchange - have been co-opted by, but also directly contributed to, the dematerialised economy of globalised financial services, predicated on the seamless, uninhibited flow of ephemeral commodities. Puncturing the tenacious belief that performance art is inherently oppositional, Sven Lütticken emphasises that contemporary performance art occurs within societies saturated with mediatised, corporatized performances: 'as anonymous services become performances, even abstract labor power has to be enacted in a personalized way by individual performers. This turns not only performance into a commodity, but ultimately the performer as well. ${ }^{43}$ Body Techniques functions pedagogically in that it interacts dialectically with the earlier works by EXPORT, Justesen, Long, Nauman, Oppenheim, Ruckreim and Ukeles, using them as sites through which to consider the history of performance as an art form, but also its role in the commodification of embodied experience.

This dynamic becomes particularly marked when Young addresses the feminist precedents set by EXPORT, Justesen and Ukeles. In Body Techniques (after Hartford Wash: Washing, Tracks, Maintenance: Outside, Mierle Laderman Ukeles, 1973), Young emulates the interventions Ukeles executed in 1973 at the Wadsworth Atheneum in conjunction with Lucy R. Lippard's exhibition $c .7,500$, which was devoted to women conceptual artists. ${ }^{44}$ Young mops the steps of an incomplete, vaguely futuristic conglomeration of curved buildings, the exact purpose of which is unclear (Figure 2). Empty windows awaiting glass gape blankly in their facades. The web of scaffolding laced over the front of the towers establishes an impression of intense precariousness, enhanced by the jumble of poles to the left of the image, and the abandoned-looking contraption on the right. These structures loom above Young, 
who appears vulnerable and out of place, despite the protective carapace of her trouser suit. Ukeles brought repressed labour coded as 'feminine' into view, and exposed the supposedly 'private' maintenance acts propping up the illusion of a separate 'public' realm, in the context of an avowedly feminist exhibition (Figure 3). ${ }^{45}$ Young's action, however, appears dislocated from potential collectivism or activism.

Despite the androgynous figure Young cuts in her trouser suit, Body Techniques (after Hartford Wash) not only exposes the continued reliance of service economies on demanding physical labour, but shows how, as Kathi Weeks maintains, these are predominantly 'feminized modes of labor - marginalized by, but nonetheless fundamental to, capitalist valorization processes'. ${ }^{46}$ Young's work establishes a direct continuum with Ukeles' feminist analysis, but also powerfully illuminates the importance of updating second wave feminism's insights in response to the conditions of global capital, including the rise of the private sector, and the atomisation of everyday life under advanced consumer capitalism. Body Techniques meditates on the dilemma expressed by Shannon Jackson when she observes that: 'if progressive artists and critics unthinkingly echo a routinized language of anti-institutionalism and antistatism, we can find ourselves unexpectedly colluding with neoliberal impulses that want to dismantle public institutions of human welfare. ${ }^{47}$ Rather than looking back nostalgically to an earlier model of institutional critique, Young asks what happens when institutions crumble and vanish, and how individual bodies adapt to, but might also resist, the challenges of the ensuing physical and psychic terrains.

Young's negotiation of the performative pressure exerted by Ukeles' work participates in a prominent strand of feminist engagements with performative afterlife. The pedagogic aspect of this return is both conceptual and materialist. Its materialism can be rooted in the prioritization of research and information gathering that characterised artistic reactions to the Women's Liberation Movement in the 1970s. Faith Wilding describes how, when 'searching for female precursors in art' during the first iteration of the Feminist Art Program at Fresno State College from 1970-71, she and her fellow students discovered that few study materials existed' ${ }^{48}$ Excavating the histories of neglected women artists played a significant role in auto-didacticism and consciousness-raising, resulting in slide libraries, bibliographies, biographies and new histories. During the last two decades, impelled by the realization that works by feminist practitioners from the 1970s have in turn been lost from view, artists, curators and historians have added re-enactment to this list of feminist historiographical tools, resulting in trans-generational feminist returns and reappraisals by artists of their own earlier work. ${ }^{49}$

Between 2007 and 2009, prompted by two feminist curatorial projects, Wilding readdressed her 1972 performance Waiting. ${ }^{50}$ During Waiting, which was first presented in the Los Angeles Womanhouse, Wilding rocked back and forth in a seated position as she recited a litany of suspended actions imposed by gendered notions of behaviour:

[...] Waiting for my breasts to develop

Waiting to wear a bra

Waiting to menstruate

Waiting to read forbidden books $[\ldots]^{51}$ 
When invited to revisit the performance, Wilding eschewed reiteration, instead reenacting Waiting through the use of recording technology, which enabled her to interweave her voice with that of other interlocutors, including Samuel Beckett and Gregg Bordowitz. Wait-With, Amelia Jones argues, witnessed a shift from Waiting's emphasis on deferred gratification, to present-tense communality and polyvocality (Figure 4). ${ }^{52}$ This openness to reformulation is a fitting testament to Waiting's genesis within a feminist pedagogic context. Wilding acted as a graduate teaching assistant on Judy Chicago and Miriam Schapiro's Feminist Art Program when it moved from Fresno to CalArts in $1971 .{ }^{53}$ She participated in the off-site Womanhouse initiative whereby Chicago, Schapiro and their students took over a dilapidated house in Hollywood, transforming it into an installation environment that provided a stage for discussions and performances. Womanhouse and the Feminist Art Program were highly conflictual, as the women grappled with power structures and competition; Wait-With continues this spirit of pedagogic contestation, treating the originary work as an adaptable lesson plan rather than a fixed formula. ${ }^{54}$

Unbeknownst to Wilding at the time, in 2007 the artist Kate Davis also re-examined Waiting. ${ }^{55}$ For Waiting in 1972, What About 2007? (2007) Davis created drawings, an installation and a photo-book that engaged the pedagogic potential of the performative by treating Wilding's work dialogically. Davis executed several nude pencil selfportraits in which the silhouette of an easel blocks out sections of her body. The installation placed these together with old television monitors, from which Davis removed the screens and electronic innards. Davis placed ceramic batons within each disembowelled shell in a reference to the modernist potter Lucie Rie. The accompanying photo-book contains black and white images of feet standing next to miscellaneous empty vessels, including a jar, a saucepan, and a plastic funnel (Figure 5). Davis' response to Wilding is constructed around the metaphor of containment; these receptacles, her title implies, are waiting for something that has not yet fully arrived, but by bringing Wilding and Rie's earlier work into performative operation, Davis' work nonetheless functions as a means of passing on knowledge.

In Davis' elliptical but sensitive back-and-forth exchange with Wilding's practice, a performance that developed in a pedagogic environment became a template that could be used to assess current conditions. The pedagogic and performative operate in tandem, as the work initiates trans-temporal dialogues, counters hierarchies of authorship, and articulates possibilities for breaking with, rather than simply replicating, a status quo based on patriarchal oppression, exclusion, and oppressive binary notions of gender. For Davis, Wait-With invited the audience to question 'how the meaning of Waiting has evolved for Wilding and others' and thereby consider 'what the political, social and personal repercussions of that action signify today'. ${ }^{56}$ The danger of re-enactment is that it might result in ossification and commodification, and prove little more than a way of easing a work's entrance into the museum complex. Equally, the fetishization of documentation raises the threat of what Mathias Danbolt calls 'archival mummification'. ${ }^{57}$ Performative pedagogy acknowledges these possible pitfalls by treating the work as a prompt for learning.

In the examples by Young and Davis, the pedagogic relationship with the source material is implicit rather than explicit, but elsewhere this power dynamic comes more strongly to the fore. Clifford Owens' Anthology initiative, first exhibited at 
MoMA PS1, New York in 2011-12, forms a compelling example. ${ }^{58}$ For Anthology, Owens commissioned scores from different generations of African American artists, including William Pope.L, Senga Nengudi, Maren Hassinger and David Hammons. These scores, together with photographic and video documentation from Owens' enactments of each submission, were displayed during the exhibition. Anthology was directly motivated by Owens' conviction that many of the art students he encountered were unaware of performance art histories, and that, more specifically, they had little knowledge of the important performances by African American artists. ${ }^{59}$

While significant scholarly and curatorial contributions have sought to fill these lacunae, performances by artists of colour remain under-studied in comparison to well-known, oft-reproduced works by white artists in the US. ${ }^{60}$ The dilemma Owens faced in grappling with this situation intersects with efforts to continue the afterlives of queer and feminist performances in ways that do not compromise their commitment to ephemerality, embodiment and opposition, or attempt to smooth over critical deconstructions of canons and authority figures. Owens' solution was an elegant one. Instead of reinventing or re-enacting so-called 'historic' works of performance, the compilation of new scores, and ensuing dialogue with their creators, resulted in an 'anthology' or educational primer - in the form of the exhibition itself, and the accompanying publication of the scores. Both exhibition and catalogue anticipate being used as learning tools, but they contain prompts for reformulation, contestation and change, rather than reiterating received forms. ${ }^{61}$

The performative pedagogy of Anthology is apparent in many of the works created through the project, such as Owens' performance of a score written by Maren Hassinger. Hassinger, who trained initially as a dancer, has created sculpture and performances since the late 1970s. During this decade, Hassinger 'activated' sculptures made of intricate webs of nylon stockings by fellow artist Senga Nengudi as part of her R.S.V.P series. In one 1977 photograph from the Pearl C. Woods Gallery in Los Angeles, Hassinger balances in a crouch on her hands and tiptoes, appraising the viewer guardedly from between her legs, which are attached to the walls by tendon-like pairs of tights, in a powerful manifestation of confinement and constriction. ${ }^{62}$ Hassinger's Anthology score, Repose, similarly addresses the ways in which constructs of gender and race converge at the site of embodiment, and how these are often projected onto, but also potentially undone by, the body itself. Hassinger conceived of the piece as 'a reprieve from action', comprising ' 5 positions of repose with 1 sigh to repeat 5 times', which included the possibility that Owens could ask for 'audience accompaniment' if desired. ${ }^{63}$ In the event, Owens decided both to involve the audience, and to perform Hassinger's directions nude.

Performance photographs track the resulting interactions as they veer between awkward, clumsy and gentle; some people look determined and serious, while others smile with a hint of embarrassment. One image shows the audience lifting Owens so that his body is suspended diagonally in a tableau suggestive of a collective Pietà, an inference underscored by the documentation's arrangement as a triptych (Figure 6). Owens' penis is tucked between his legs, so that the body presented here is destabilised and ambiguous, undercutting pervasive negative stereotypes of black masculinity while registering the violence directed against black bodies, suturing the work to the contestation of physical and psychic limitations explored by Nengudi and Hassinger in their earlier collaboration. 
Through commissioning and performing Repose, Owens engaged Hassinger in a reciprocal teacher-student relationship, adopting the role of a learner who, by executing her score, would gain personal knowledge while developing shared educational resources for a wider community. Hassinger's conceptualisation of Repose as a 'reprieve from action' is especially evocative in this respect. Although the work enables rest, it also demarcates space and time for reflection and the consolidation of insights gained from experience. Anthology is overtly generational in its construction; Hassinger and other artists are cast as predecessors with vital lessons to share, and stores of experience that need to be collected and passed on, echoing Davis' use of the vessel metaphor in Waiting in 1972, What About 2007? Like Davis' project, however, the pedagogic implication complicates genealogical dissemination. The artists who provided scores had to hand over control to Owens, so that the exchange became lateral rather than hierarchical, and the scores/lesson plans vulnerable to creative alteration.

At points in Anthology, the ambiguity around authorial control provoked outbreaks of tension, exemplifying how the pedagogic performative encompasses contestation as well as collaboration. Kara Walker provided Owens with a score that directed him to 'French kiss' an audience member, and to 'demand sex' from another; if they were 'willing to participate in the forced sex act', then Owens was instructed to 'abruptly turn the tables and [...] assume the role of victim' ${ }^{64}$ Concerned by the aggression that this challenging score threatened to unleash, Walker attended the PS1 performance. As it unfolded, 'she shadowed Owens as he stalked the room', a protective and defensive gesture which highlighted 'the duplicitous nature of the instructions', together with the fraught issue of directorial control. ${ }^{65}$ Equally, the contingency of Walker and Owens' interaction exemplified the radical performativity that the pedagogic process can achieve, through which unforeseen positions and possibilities might be trialled and interrogated.

\section{Coda: Challenging Pedagogy}

Performative pedagogy, then, entails dissention as much as reciprocity; this coda addresses pedagogic questioning, critique, divergence and disagreement through Patrick Staff's video work The Foundation (2014), which evolved in response to the artist's encounter with the Tom of Finland Foundation in Los Angeles. This organization began as a collective house in LA's Echo Park neighbourhood during the 1970s, when a group of men bought the building together and inhabited it 'as a sort of intentional community of gay leathermen' ${ }^{66}$ Several group members were admirers of the artist Tom of Finland (Touko Laaksonen), whose intensely homoerotic, macho drawings - particularly of leathermen and soldiers - had achieved cult status by the 70s. Laaksonen travelled regularly to the US following his first exhibition in LA during 1978 and stayed at the house, becoming a 'familiar face' on the LA leather scene. ${ }^{67}$ In 1984 the building was transformed into a non-profit foundation dedicated to preserving his work and ephemera, together with a growing archive of erotic art, while also continuing to function as a community space and informal hostel.

Between 2012 and 2014, Staff visited LA from the UK on multiple occasions, volunteering at the Foundation and assisting with archival cataloguing. Staff gathered 
footage for The Foundation on an iPhone while helping out, as well as during a visit with a camera crew. In the final video, these sections of material are woven together to create an intimate documentary portrait of the Foundation's multiple functions domestic, archival, communal, erotic, administrative and educational. Light filters into the cave-like space of the wooden Craftsman building, its interior protected from the California sun by venetian blinds. A ceiling fan gently rotates as people quietly attend to their various tasks. Paintings, drawings and sculptures crowd the walls and surfaces, interspersed with tumescent dildos. These documentary shots are, however, disrupted by a sudden relocation to a dramatically different scene. This contrapuntal theatrical space contains a platform constructed from metal bars and slats of wood, harshly illuminated by overhead lights. ${ }^{68}$ On this stage, two figures enter into a dance, accompanied by music with a propulsive industrial beat, gleaned from a film in the Foundation's collection. ${ }^{69}$ Staff, wearing slim black pants and a leather hoist over their sholders, plays one of these characters; their light blond hair, tied up in a bun, together with the traces of make-up around their eyes and lips, contrast markedly with the other dancer, a stern-looking middle-aged man dressed in a grey t-shirt and apron, whose beard and musculature evoke Tom of Finland's fetishized fantasy objects.

These two personages manifest the conflicted set of relations that the Tom of Finland Foundation came to encapsulate for Staff: 'my experience of that place is so thick and so heavy with representation. [...] It is a very male, masculine-oriented scene which my queer, trans identity really presses against' ${ }^{70}$ Their dance is rife with struggle and simmers with latent violence. Staff and the leather daddy stand side by side and move in unison, snake-hipped but stony-faced, their gazes rarely if ever meeting (Figure 7). During one sequence in which they swap clothes and, by implication, their roles start to blur, the latter positions Staff's arms and hands, leaving ink-like smudges and smears that record the progress of his didactic touch (Figure 8). The bearded figure intones with an air of menace: 'You'll get used to it, being a man.' At the same time, Staff stresses the vital role of organisations such as the Tom of Finland Foundation in protecting and preserving subcultural lives and archives, and in enabling bonds to be established across different temporal moments in gay, queer and trans histories. In particular, Staff notes the danger of disavowing 'a certain lineage and generation towards which we have a responsibility. By which I mean a younger generation's responsibility to a generation largely constituted of the dead. ${ }^{, 71}$ Staff's work questions how queer and non-binary subjects who have come of age in the aftermath of AIDS can ensure they are educated about a lost generation and actively participate in its memorialization, while forging and testing alternative identity formations. ${ }^{72}$

The Foundation makes space for the importance of Tom of Finland's contribution, which S. R. Sharp locates less in the explicit sexual acts represented, but rather in the more 'subliminal' effect of their sex-positive, non-shaming ethos. ${ }^{73}$ The dynamic of domination in The Foundation is redolent of both BDSM role-play and the pedagogic set-up. BDSM and pedagogy are intimately intertwined in the histories of sexuality and identity nurtured by the Foundation; Catherine Lord identifies the 'whips and chains, slings and boots, uniforms and lube', neatly arranged in the functioning sexdungeon that continues to occupy the basement of the house, as 'the props of a classroom'. ${ }^{74}$ While the teacher-student relationship between the two figures seethes with antagonism, it thus also testifies to shared histories that can be simultaneously registered, and critiqued productively. 
Staff might in this sense be said to continue Leo Bersani's analysis of hypermasculinity in relation to the AIDS crisis, whereby he argues for the importance of struggling 'not only against definitions of maleness and of homosexuality as they are reiterated and imposed in a heterosexist social discourse, but also against those very same definitions so seductively and so faithfully reflected by those (in large part culturally invented and elaborated) male bodies that we carry within us as permanently renewable sources of excitement. ${ }^{75}$ Staff's sensation of 'pressing against' the histories of the Tom of Finland Foundation offers a mode of resistance to oppressive models of masculinity, particularly their connections with militarism and fascism, and the possibility of retaining connections across difference which acknowledge the imbrication of politics and erotics. ${ }^{76}$

Staff's desire to establish trans-generational conduits that might facilitate questioning and dialogue around gender identity resonates with theorizations of queer temporality, the returns, repetitions and ellipses of which contrast with what Muñoz summarizes as the 'autonaturalizing temporality that we might call straight time', in which 'the only futurity promised is that of reproductive majoritarian heterosexuality, the spectacle of the state refurbishing its ranks through overt and subsidized acts of reproduction. ${ }^{77}$

The Foundation stages generational difference to try and break through genealogy and achieve anachronistic, cross-temporal connection, whereby being 'out-of-joint' might enable relation, rather than conformist reiteration. In a valuable examination of the relationship between queer feminist re-enactment and pedagogy, Catherine Grant employs Bertolt Brecht's concept of the 'learning play' to explore the inter-subjective connections forged through the rehearsal process. ${ }^{78}$ Significantly, Grant reads the trope of 'temporal disruption as a space of possibility' that permeates the literature on re-enactment as 'a space of learning' ${ }^{79}$ Staff's disorientating combination of documentary, archival and theatrical registers in The Foundation operates in this way, although Staff highlights the danger that the 'space of learning' might involve disciplinary control as well as ludic possibility.

Sometimes the teacher-student relationship portrayed in The Foundation seems physically and psychically painful and restrictive, as one body is forced in line with another. Staff has described watching the work and suddenly recognizing it as a portrait of 'my own gender dysphoria: my identity meltdown'. ${ }^{80}$ Yet it is in corporeality that resistance and wilfulness survives; even as the dancers synchronize their gestures, Staff's body retains the potential to break away and move differently in active, performative transformation. Kris Grey and Jennie Klein argue that 'Trans* implies a performative, non-fixed engagement with identity, history, time, and geography', and a sense of this infuses Staff's forcefully embodied, but steadfastly gender nonconforming reaction to the archival afterlife cared for by the Tom of Finland Foundation. ${ }^{81}$ The Foundation considers the distinctions between gay, queer and trans identities, but implicitly asks how overlaps and intersections between these positions might foster education, understanding and solidarity. ${ }^{82}$ Here, performative pedagogy has the capacity to be liberatory and restrictive, but ultimately offers a way of working through antagonistic relationships. This enables relational configurations and positions of difference to be shaped, recognized, and respected. Young, Davis, Owens and Staff create diverse bodies of work, underlining the myriad pedagogic possibilities that have developed from artistic afterlives. Each, however, proceeds from the conviction that pedagogic processes, through their performative capacity, 
can occasion growth and change.

\section{Notes}

Thanks to Amelia Jones for her insightful comments on an earlier draft; Amy Tobin for continued interlocution; and Kate Davis, Clifford Owens, Mierle Laderman Ukeles, Patrick Staff, Faith Wilding and Carey Young for generosity with images.

${ }^{1}$ Writing on socially engaged art has arguably investigated the relationship between pedagogy, performance and the performative to the greatest extent. See Finkelpearl, What We Made; Bishop, 'Pedagogic Projects'; Jackson, Social Works; Kester, Conversation Pieces; Kester, The One and the Many; and Lacy, Leaving Art. Adair Rounthwaite, analysing participatory art in 1980s New York, makes a valuable connection between pedagogy and the performative, noting that in collaborative practice 'education has come to function rhetorically as the performative instantiation of aesthetic experience'. Rounthwaite, 'The Pedagogical Subject of Participation,' 77. For two studies of performance art that specifically address its relationship with pedagogy, see Bryan-Wilson, 'Practicing Trio A'; and Grant, 'A Time of One's Own.' ${ }^{2}$ Diana Taylor argues that embodied actions can have just as much of an afterlife as archival documents. See Taylor, The Archive and the Repertoire. For an important account of the ways in which performance endures through documents and bodily repertoires, see Schneider, Performing Remains. Taylor and Schneider draw on, but nuance, Peggy Phelan's foundational defence of ephemerality, which equates transience with resistance to commodification and essentializing identity constructs. See Phelan, Unmarked.

${ }^{3}$ I am building here on arguments that performance documentation is in and of itself performative, especially Auslander, 'The Performativity of Performance Documentation.' For an illuminating expansion of Auslander's ideas, see Widrich, Performative Monuments, particularly 13-52. Christian Berger and Jessica Santone contend that even during the $1960 \mathrm{~s}$, 'the potential for documentation to somehow restage site-specific or performative works for other audiences was compelling.' Berger and Santone, 'Documentation as Art Practice in the 1960s,' 204. For mediation's role in live art, see also Giannachi and Westerman, eds., Histories of Performance Documentation; Maude-Roxby, ed., Live Art on Camera; and Auslander, Liveness. ${ }^{4}$ These include A Short History of Performance: Part 1 (2002), Part II (2003), Part III (2005) and Part IV (2006) at the Whitechapel Gallery, London; Life, Once More: Forms of Reenactment in Contemporary Art (2005) at Witte de With, Rotterdam; Ahistoric Occasion: Artists Making History (2007) at the Massachusetts Museum of Contemporary Art; and Not Quite How I Remember It (2008), at the Power Plant, Toronto. For a timeline of re-enactment, see Jones, 'Timeline of Ideas.' For specific aspects of the phenomenon, see Blackson, 'Once More... with Feeling'; Tomic, 'Fidelity to Failure'; and Jones, ed. 'Forum: Performance, Live or Dead.'

${ }^{5}$ See for example Widrich, "Is the "Re" in Re-enactment the "Re" in Reperformance?'

${ }^{6}$ In this respect I follow Grant, who uses Schneider to think through the expansive possibilities of re-enactment. Grant, 'A Time of One's Own,' 361-2. This converges to some extent with the artist Allan Kaprow's preference for 'reinvention', which curator Philippe Pirotte explains, enabled his scores to be adapted 'to the moment and to the issues, themes, and fashions of the day - as long as the "central metaphor" [...] was maintained.' Pirotte, 'Participation: A Legacy of Allan Kaprow,' not paginated. 
On Kaprow and reinvention, see Tomic, 'Reinvention as Parallax'; Holte, 'Happening Again'; and Buskirk, 'Kaprow's Vector.'

${ }^{7}$ Tarsia, 'Towards a Short History of Performance,' 34. Tarsia reflects here on his curatorial involvement in A Short History of Performance, for Notes on a Return, an exhibition curated by Sophia Yadong Hao that was also concerned with recreation. See Hao, 'Memory Is Not Transparent.'

${ }^{8}$ The imbrication of performance, capital, spectacle, and institutions is incisively critiqued in Foster, 'In Praise of Actuality'; Siegelbaum, 'Business Casual'; Lütticken, 'Progressive Striptease'; and Lütticken, 'An Arena in Which to Reenact.' The academic consolidation of performance studies has also contributed to the historicization process, although a disciplinary divide between performance studies and performance art history remains. See Jackson, Professing Performance.

${ }^{9}$ Roms, 'Archiving Legacies,' 37.

${ }^{10}$ hooks, Teaching to Transgress, 11.

${ }^{11}$ Muñoz, 'Teaching, Minoritarian Knowledge, and Love.'

12 Austin, How to Do Things with Words, 6. Austin rejected a rigid notion of the performative, emphasising the "many transitional stages between suiting the action to the word and the pure performative.' Austin, How to Do Things with Words, 81 .

${ }^{13}$ Butler, Bodies That Matter, 225. For Butler's foundational work on performativity and gender, see Butler, Gender Trouble.

${ }^{14}$ Butler, Bodies That Matter, 241.

${ }^{15}$ hooks, Teaching to Transgress, 11. For a useful discussion of distinctions between 'performance' and 'performative', see Reinelt, 'The Politics of Discourse.'

${ }^{16}$ Sedgwick, Touching Feeling, 34.

${ }^{17}$ Sedgwick, Touching Feeling, 34.

${ }^{18}$ Sedgwick, Touching Feeling, 17. Sedgwick cites Jacques Derrida's reading of Austin, which emphasises 'the fatal and formal constraint of a performative effect'. Derrida, Archive Fever, 67.

${ }^{19}$ Felman, The Literary Speech Act, 126.

${ }^{20}$ Felman, The Literary Speech Act, 126.

${ }^{21}$ Felman, The Literary Speech Act, 104-5.

${ }^{22}$ Muñoz, 'Teaching, Minoritarian Knowledge, and Love,' 118.

${ }^{23}$ See Halberstam, The Queer Art of Failure, particularly 87-121.

${ }^{24}$ Schor, 'Authority and Learning,' 134.

${ }^{25}$ hooks, 'Paulo Freire,' in Teaching to Transgress, 45-58.

${ }^{26}$ Freire, Pedagogy of the Oppressed, 54.

${ }^{27}$ See Finkelpearl, What We Made, especially 1-50 and 343-61. See also Lacy, Leaving Art; and Lacy, ed., Mapping the Terrain.

${ }^{28}$ Phillips, 'Education Aesthetics,' 84.

${ }^{29}$ The pedagogic function of performance can also be linked to its history within art schools; Elena Crippa traces how the performance-lecture emerged from this context during the 1960s and 1970s. See Crippa, 'The Artist as a Speaker-Performer.'

${ }^{30}$ Allen, 'Introduction//Art: Education,' 12. See also Rogoff, 'Turning,' 34. For the education system's replication of cultural capital, see Bourdieu, 'Cultural Reproduction and Social Reproduction.'

${ }^{31}$ Rogoff, 'Academy as Potentiality,' 19.

${ }^{32}$ Paul O'Neill and Mick Wilson note that 'unlike the term pedagogy etymologically, the art of teaching the child - education does not privilege the theme of teaching over that of learning and, unlike pedagogy (with its complementary 
construct, andragogy), education is not etymologically posited upon the adult/child distinction.' Rather than 'education', I employ the term 'pedagogy' precisely because this unequal power relation is one that many artists deliberately explore. O'Neill and Wilson, 'Introduction,' 15-16.

${ }^{33}$ Hayes' work is discussed in Schneider, Performing Remains, 169-186; Grant, 'Fans of Feminism'; and Reckitt, 'To Make Time Appear.'

${ }^{34}$ On Hayes' relationship with the performative, see Greaney, Quotational Practices, 115-154.

${ }^{35}$ Sharon Hayes, in Bryan-Wilson, 'We Have a Future,' 88.

${ }^{36}$ Jones, "The Artist Is Present",' 19.

${ }^{37}$ Widrich observes that Abramović based her re-performances 'consciously on the photographic documents she knew', approaching the works as images. Widrich, 'Can Photographs Make It So?,' 98. Abramović's promotion of a performance art canon risks ignoring feminist critiques of canon formation. See Pollock, Differencing the Canon, particularly 3-21.

${ }^{38}$ Young employs the term 're-works' on her website. http://www.careyyoung.com/works\#/body-techniques/ [Accessed 15 August 2017]. ${ }^{39}$ Young, 'Unfinished Business,' 145.

${ }^{40}$ See Mauss, 'Techniques of the Body.'

${ }^{41}$ This is underscored by the work's execution within the context of the Sharjah Biennial's Artist in Residence Program.

42 Farquharson, 'The Avant-Garde, Again,' 17.

${ }^{43}$ Lütticken, 'Progressive Striptease,' 194.

${ }^{44}$ For a history of the exhibition series to which this belonged, see Butler, ed., From Conceptualism to Feminism.

${ }^{45}$ See Molesworth, 'House Work and Art Work,' 76-78.

${ }^{46}$ Weeks, The Problem with Work, 26. On artistic engagements with the feminization of labour in relation to globalisation, see also Dimitrakaki, Gender, ArtWork and the Global Imperative.

${ }^{47}$ Jackson, Social Works, 16. On performance art and neoliberalism see also Harvie, Fair Play.

${ }^{48}$ Wilding, 'The Feminist Art Programs at Fresno and CalArts, 1970-75,' 38.

${ }^{49}$ On the erasure of feminist work from definitions of 'relational aesthetics' during the 2000s, see Jones, 'Unpredictable Temporalities,' and Reckitt, 'Forgotten Relations.'

${ }^{50}$ Wilding was invited to revisit the work in conjunction with WACK! Art and the Feminist Revolution, and re.act.feminism. See Mark, ed. WACK! and for the second iteration of the latter project, Knaup and Stammer, eds., Re.Act.Feminism \#2.

${ }^{51}$ Faith Wilding, 'Waiting: A Poem by Faith Wilding' (1972), in Jones, 'Faith Wilding, Waiting and Wait-With,' 255-258.

52 Jones, 'Faith Wilding, Waiting and Wait-With,' 254.

${ }^{53}$ Wilding, 'The Feminist Art Programs at Fresno and CalArts, 1970-75,' 39.

${ }^{54}$ On Womanhouse see also Chicago, Through the Flower, particularly 93-111 and 112-132. For the afterlives of Womanhouse in the UK, see Tobin, 14 Radnor Terrace; and Hamblin, 'Los Angeles, 1972/Glasgow, 1990.'

${ }^{55}$ For an insightful examination of Davis' work and re-vision as a feminist strategy, see Horne, 'Kate Davis.'

${ }^{56}$ Davis, in Bowman and Davis, 'What Are You Doing it For?,' 111. As a result of their simultaneous investigation of Waiting in 2007, Wilding and Davis exhibited 
together at Glasgow's Centre for Contemporary Arts in 2010. See Davis and Wilding, The Long Loch.

${ }^{57}$ Danbolt stresses that 'merely gathering documentation of feminist performance art is far from enough to preserve queer and feminist art movements.' Danbolt, 'Arresting Performance,' 99.

${ }^{58}$ In 2014, Owens continued Anthology during his exhibition Better the Devil You Know at Cornerhouse, Manchester, commissioning scores from UK artists whose work addresses race and representation, including Lubaina Himid, John Akomfrah and Lynette Yiadom-Boakye.

${ }^{59}$ Clifford Owens, in Stillman, 'Interview with Clifford Owens,' 52.

${ }^{60}$ See Cheng, In Other Los Angeleses; Bowles, Adrian Piper; Smith, Enacting Others; Oliver, ed., Radical Presence; McMillan, Embodied Avatars; and Jones, South of Pico, particularly 185-263 on performances by Maren Hassinger, Senga Nengudi, Houston Conwell, and David Hammons.

${ }^{61}$ The catalogue references the scores using sequential letters of the alphabet rather than page numbers, underlining this inference.

${ }^{62}$ On Nengudi and Hassinger see Jones, South of Pico, particularly 192-211; and Jones, Now Dig This!, 264-303. Hassinger re-performed the work in 2013 as part of Radical Presence.

${ }^{63}$ Maren Hassinger, 'Repose,' 2011, in Owens, Anthology, C.

${ }^{64}$ Kara Walker, 'Instruction,' 2011, in Owens, Anthology, R. Owens includes the email exchange which evolved between him and Walker, in which they discuss the ensuing media attention, and their alterations of the score's parameters.

${ }^{65}$ Lew, 'Trust Me,' 52.

${ }^{66}$ Staff, interview with Guggenheim, 114.

${ }^{67}$ Ramakers, 'The Art of Pleasure,' 26.

${ }^{68}$ Staff describes this as 'a sort of spatial set of the house'. Staff, in 'A Structural Idea of Fluidity,' 282.

${ }^{69}$ Staff, interview with Guggenheim, 116.

${ }^{70}$ Staff, in 'A Structural Idea of Fluidity,' 281. Staff reflects: 'to say that I'm trans, but to also be assigned male at birth and presenting as pretty masculine, I can be seen as a kind of dilettante, or just a man playing with ideas. It's a very particular gap, and one that actually a lot of people exist in. Society grants us very little freedom in our gender.' Staff, interview with Guggenheim, 120. Jack Halberstam observes that 'the transgender body is not reducible to the transsexual body, and it retains the marks of its own ambiguity and ambivalence.' Halberstam, In a Queer Time and Place, 97. See also Preciado, Testo Junkie, particularly 99-129.

${ }^{71}$ Staff, in 'A Structural Idea of Fluidity,' 281.

${ }^{72}$ Douglas Crimp movingly reflects on this disjunction in 'Mourning and Militancy.' For an important critique of the dynamic of relation and forgetting that Staff addresses, see also Schulman, The Gentrification of the Mind.

${ }^{73}$ Sharp, interview with Staff, 12.

${ }^{74}$ Lord, 'The Fourth Pussy,' 17.

${ }^{75}$ Bersani, 'Is the Rectum a Grave?' 209.

${ }^{76}$ Laaksonen's enthusiasm for uniforms has been attributed to his experience as a solider in Finland during World War II, which swung between support for the allies and allegiance to Germany; his sexualised portrayals of Nazi soldiers remain highly contentious. Ramakers, 'The Art of Pleasure,' 26. 
${ }^{77}$ Muñoz, Cruising Utopia, 22. Muñoz draws here on Lee Edelman's polemic No Future, but also marks his divergence from it, refusing 'to give up on concepts such as politics, hope, and a future that is not kid stuff.' Muñoz, Cruising Utopia, 92. See also Edelman, No Future; Freeman, Time Binds; and Dinshaw et al., 'Theorizing Queer Temporalities.'

${ }^{78}$ Grant, 'A Time of One's Own,' 360.

${ }^{79}$ Grant, 'A Time of One's Own,' 362.

${ }^{80}$ Staff, interview with Guggenheim, 120.

${ }^{81}$ Grey and Klein note that the * in Trans* constitutes 'a linguistic manifestation that aims to umbrella many different identities, bodies, and configurations' that defy 'gendered conventions and expectations'. Grey and Klein, 'Trans*feminism,' 321. For wide-ranging discussions of Trans* identity and performance, see Jones, ed. 'On Trans/Performance.' See also Stryker, 'The Transgender Issue: An Introduction.'

${ }^{82}$ Butler reflects that: 'many trans people, or trans advocates, have argued that queer is exclusionary, that it does not include or describe trans experience.' Butler, in Ahmed, 'Interview with Judith Butler,' 490. 